\title{
HELMINTOS PARÁSITOS DE Paralichthys californicus (OSTEICHTHYES: PARALICHTHYDAE) EN EL ESTERO DE PUNTA BANDA, BAHÍA DE TODOS SANTOS Y BAHÍA DE SAN QUINTÍN, BAJA CALIFORNIA, MÉXICO
}

\section{HELMINTH PARASITES OF Paralichthys californicus (OSTEICHTHYES: PARALICHTHYDAE) IN ESTERO DE PUNTA BANDA, TODOS SANTOS BAY AND SAN QUINTÍN BAY, BAJA CALIFORNIA, MEXICO}

\author{
Elizabeth Castillo-Sánche $z^{\mathrm{t} .2}$ \\ J.A. Rosales-Casián ${ }^{2}$ \\ G. Pérez-Ponce de León ${ }^{1}$ \\ ' L aboratorio de Helmintología \\ Instituto de Biologia \\ Universidad Nacional Autónoma de México \\ Apartado postal 70-153 \\ CP 04510, México, DF
${ }^{2}$ Centro de Investigación Científica y de Educación Superior de Ensenada (CICESE)
Apartado postal 2732
Ensenada, Baja California, México

Recibido en febrero de 1998; aceptado en agosto de 1998

\section{RESUMEN}

Se establece el registro helmintológico del lenguado de California, Paralichthys californicus, en el Estero de Punta Banda, Bahía de Todos Santos y Bahía de San Quintín, Baja California, México. Se analizaron 102 individuos y se identificaron 14 especies de helmintos: seis fueron trematodos adultos (Stephanostomum dentatum, Criptogoniminae, Metadena magdalenae, Opegaster parapristipomatis, Parahemiurus merus y Tubulovesicula lindbergi); seis nematodos (Spirocamallanus pereirai, Philometra sp. y Hysterothylacium sp. en estadio adulto, y Anisakis sp., Contracaecum sp. y Porrocaecum sp. como larvas); un cestodo (Tetraphyllidea); y un acantocéfalo (Corynosoma strumosum) en estadio larvario. En los tres sitios, las larvas de Anisakis sp. y los plerocercos del orden Tetraphyllidea fueron importantes por sus altos valores de abundancia y prevalencia. Anisakis sp. es importante para el hombre ya que puede ser un riesgo a la enfermedad denominada Anisakiasis.

Palabras clave: helmintos, parásitos, Paralichthys californicus, Baja California, México.

\begin{abstract}
The helminthological record of the California halibut, Paralichthys californicus, in Estero de Punta Banda, Todos Santos Bay and San Quintín Bay, Baja California, Mexico, is described. A total of 102 halibut was analyzed and 14 helminth species were identified: six were adult trematodes
\end{abstract}


(Stephanostomum dentatum, Criptogoniminae, Metadena magdalenae, Opegaster parapristipomatis, Parahemiurus merus and Tubulovesicula lindbergi); six nematodes (Spirocamallanus pereirai, Philometra sp. and Hysterothylacium sp. in the adult stage, and Anisakis sp., Contracaecum sp. and Porrocaecum sp. as larvae); a cestode (Tetraphyllidea); and an acanthocephalan (Corynosoma strumosum) in the larval stage. At the three sites, Anisakis sp. larvae and the plerocercoids from the order Tetraphyllidea were important, due to their high values of abundance and prevalence. Anisakis sp. is important for humans, because of the risk it presents for contracting anisakiasis disease.

Key words: helminths, parasites, Paralichthys californicus, Baja California, Mexico.

\section{INTRODUCCIÓN}

México cuenta con una gran extensión de ambientes marinos y de agua dulce, así como muchas especies de peces de importancia económica que se capturan de forma costera; sin embargo, poco se conoce sobre las especies de helmintos que parasitan a este grupo de hospedantes y los niveles de infecciones alcanzados por los mismos. Por tanto, su estudio es importante, sobre todo en aquellos peces comerciales como es el caso del lenguado de California, Paralichthys californicus, cuyo valor en el mercado es superior al de otras especies del mismo grupo, así como el consumo por su carne blanca en la zona de California y Baja California (Hammann y Ramírez-González, 1990).

El lenguado de California juega un papel importante en la composición íctica de bahías y csteros, ya que sus juveniles se encuentran con altas abundancias. Esta especie es la más importante en el Estero de Punta Banda y segunda en la Bahía de San Quintín, en términos del índice de importancia de la comunidad (ICI) y determinado por su abundancia relativa y frecuencia de ocurrencia (Rosales-Casián, 1997). Sus adultos forman parte del grupo denominado "escama" que son capturados en la pesca artesanal y recreativa (Hammann y Rosales-Casián, 1990).

Los registros que existen en la literatura sobre parásitos de $P$. californicus señalan la presencia de 14 especies para la zona de California (EUA) y Baja California (México); 13 especies corresponden al grupo de endoparásitos ( 5 trematodos, 4 cestodos y 4 nematodos), así como una especie de ectoparásito en la superficie del cuerpo, el

\section{INTRODUCTION}

Mexico has vast areas of marine and freshwater environments, as well as many species of economically-important fish that are caught along its coast; however, little is known about the helminth species that parasitize this group of hosts or the levels of infection they produce. It is important to study these helminth species, especially in commercial fish, such as the California halibut, Paralichthys californicus, whose market value is greater than that of all other species of this group, and it is the most consumed in California and Baja California (Hammann and Ramírez-González, 1990).

The California halibut plays an important role in the ichthyic composition of bays and estuaries, since juveniles occur in large abundance. It is the most important species in Estero de Punta Banda and second most important in San Quintín Bay, in terms of the index of community importance (ICI), determined by its relative abundance and frequency of occurrence (Rosales-Casián, 1997). The adults form part of the group known as scale fish and are caught by artisanal and sport fishing (Hammann and Rosales-Casián, 1990).

The records that exist in the literature on parasites of $P$. californicus indicate the occurrence of 14 species in California (USA) and Baja California (Mexico); 13 correspond to endoparasites ( 5 trematodes, 4 cestodes and 4 nematodes), and one to a species of ectoparasite on the body surface, the monogenean Entobdella squamula (Heath, 1902) Johnston, 1929. These records focus on isolated taxonomic studies and none of them discuss aspects of the levels of infection for 
monogéneo Entobdella squamula (Heath, 1902) Johnston, 1929. Estos registros se enfocan a estudios taxonómicos aislados y ninguno de ellos aborda aspectos de los niveles de infección para cada una de las helmintiasis (Bane y Bane, 1971; Haaker, 1975; Love y Moser, 1983).

El objetivo de este trabajo es establecer el registro helmintológico de las especies que parasitan al lenguado de California en tres zonas de la costa occidental de Baja California: la Bahía de Todos Santos, Estero de Punta Banda y Bahía de San Quintin: asimismo, establecer los valores de abundancia y prevalencia que describen la infección por estos helmintos en $P$. californicus en las zonas de estudio.

\section{ÁREA DE ESTUDIO}

La Bahia de Todos Santos se localiza sobre la costa del Pacífico en la península de Baja California, aproximadamente a $110 \mathrm{~km}$ al sur de la frontera de México y Estados Unidos, entre los paralelos $31^{\circ} 43^{\prime}$ y $31^{\circ} 54^{\prime} \mathrm{N}$ y los meridianos $116^{\circ} 31^{\prime}$ y $116^{\circ} 49^{\prime} \mathrm{W}$ (fig. 1). Posee una superficie de $116 \mathrm{~km}^{2}$ y un $80 \%$ presenta menos de $50 \mathrm{~m}$ de profundidad; el resto forma parte del cañón submarino localizado cntre las islas de Todos Santos y Punta Banda (Secretaría de Marina, 1974).

El Estero de Punta Banda es una laguna costera en torma de $L$ (fig. 1), con una boca permanente en la parte superior; a lo largo de ésta hay un canal, cuya profundidad disminuye de la boca hacia el interior $y$ raramente excede de $8 \mathrm{~m}$ (Acosta-Ruiz y Álvarez-Borrego, 1974). La salinidad y la temperatura del agua aumentan hacia la cabeza del estero; los movimientos del agua se deben principalmente a la marea y son más fuertes en la boca, lo que permite el régimen de circulación dentro del mismo (Ibarra-Obando, 1990).

La Bahía de San Quintín es de origen volcánico y presenta una forma de $Y$; se localiza entre los paralelos $30^{\prime \prime} 24^{\prime}$ y $30^{\circ} 30^{\prime} \mathrm{N}$ y los meridianos $115^{\circ} 57^{\prime}$ y $116^{\circ} 01^{\prime} \mathrm{W}$ (fig. 1). Comprende un área de aproximadamente 4000 ha, dividida en dos brazos: el del lado oeste, denominado Bahía each of the helminths (Bane and Bane, 1971; Haaker, 1975; Love and Moser, 1983).

The objective of this study is to establish the helminthological record of the species that parasitize the California halibut in three areas of the west coast of Baja California: Todos Santos Bay, Estero de Punta Banda and San Quintín Bay; as well as to eslablish the values of abundance and prevalence that determine infection in $P$. californicus by these helminths in the study sites.

\section{STUDY AREA}

Todos Santos Bay is located on the Pacific coast of the peninsula of Baja California, approximately $110 \mathrm{~km}$ south of the US-Mexico border $\left(31^{\circ} 43^{\prime}\right.$ and $31^{\circ} 54^{\prime} \mathrm{N} ; 116^{\circ} 31^{\prime}$ and $116^{\circ} 49^{\prime} \mathrm{W}$ ) (fig. 1). It has an area of $116 \mathrm{~km}^{2}$ and $80 \%$ is less than $50 \mathrm{~m}$ deep: the rest forms part of the submarine canyon located between the Todos Santos Islands and Punta Banda (Secretaría de Marina, 1974).

Estero de Punta Banda is an $L$-shaped coastal lagoon (fig. 1), with a permanent mouth in the upper part. There is a channel that runs through it, the depth of which decreases from the mouth inwards and rarely exceeds $8 \mathrm{~m}$ (Acosta-Ruiz and Álvarez-Borrego. 1974). The salinity and temperature of the water increase towards the head of the lagoon. Water movement is due mainly to the tide. which is strong at the mouth, allowing for a circulation regime within the lagoon (IbarraObando. 1990).

San Quintín Bay is of volcanic origin and is $Y$-shaped. It is located between $30^{\circ} 24^{\prime}$ and $30^{\circ} 30^{\prime} \mathrm{N}$ and $115^{\circ} 57^{\prime}$ and $116^{\circ} 01^{\prime} \mathrm{W}$ (fig. 1). It has an approximate area of 4000 ha and is divided into two arms: the west side is called Falsa Bay and the east side San Quintín Bay. It connects with the sea through a narrow mouth, less than $1000 \mathrm{~m}$, with a depth of 2 to $7 \mathrm{~m}$, while the depths of the internal channels can be greater than $10 \mathrm{~m}$ (Contreras, 1985). 


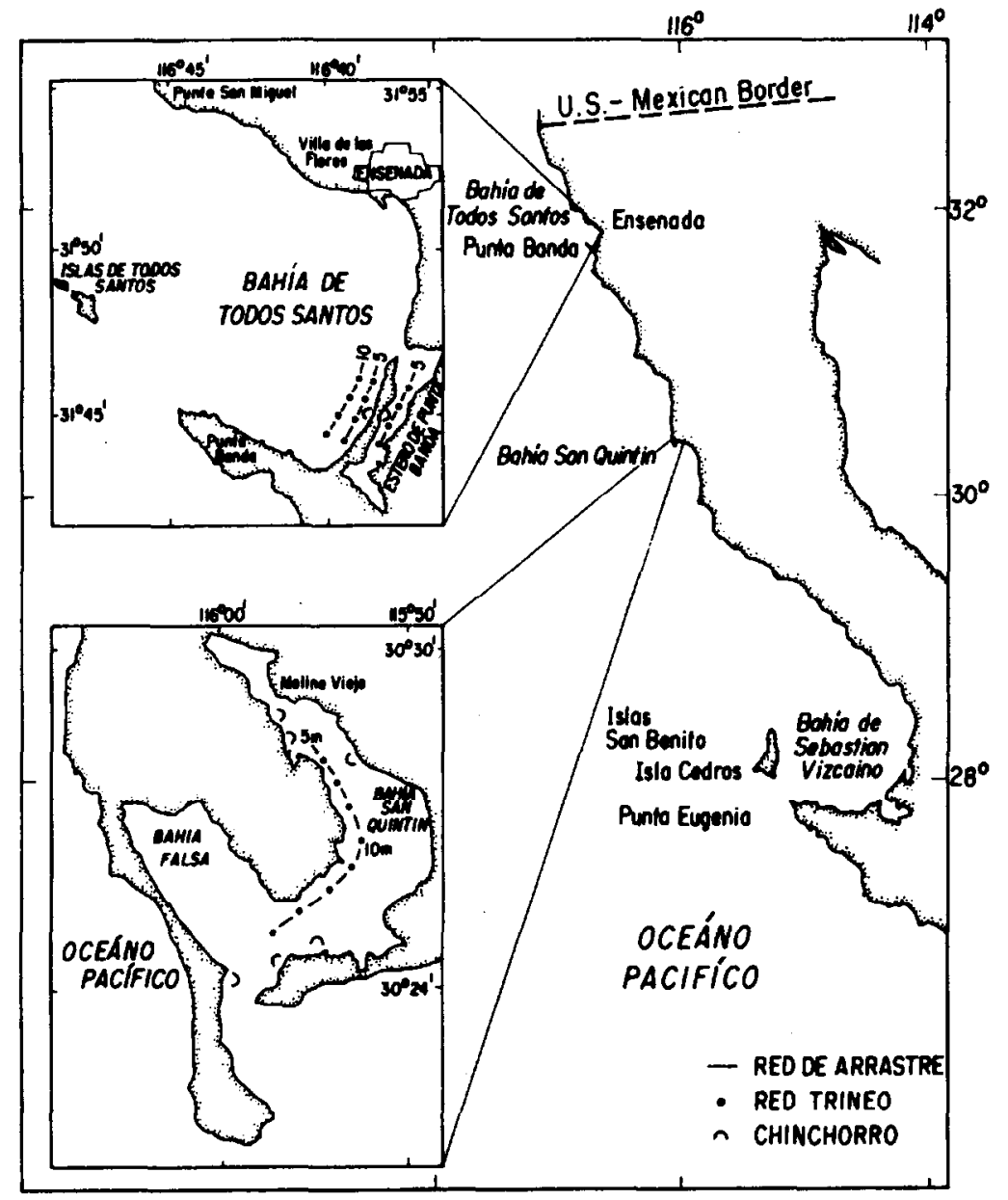

Figura 1. Localización del área de estudio y sitios de recolección. Figure 1. Location of the study arca and collection sitcs.

Falsa, y el del lado este, conocido como Bahía de San Quintín. Se comunica con el mar por medio de una boca estrecha, menor que $1000 \mathrm{~m}$, con una profundidad de 2 a $7 \mathrm{~m}$, mientras que en los canales internos la profundidad alcanza profundidades mayores que $10 \mathrm{~m}$ (Contreras, 1985).

\section{MATERIALS AND METHODS}

Four trips were made to the sites during August and September 1995. The fish were caught at 5 and $10 \mathrm{~m}$ with a beamtrawl and ottertrawl, and at $<2 \mathrm{~m}$ with a beach seine. The 


\section{MATERIALES Y MÉTODOS}

Se efectuaron cuatro visitas a los sitios durante agosto y septiembre de 1995. Los peces fueron recolectados a 5 y $10 \mathrm{~m}$, tanto con la red de prueba camaronera (chango) como la red trineo, y a $<2 \mathrm{~m}$, con la red chinchorro playero. La descripción de las artes de pesca se presenta en KosalesCasián (1996). Se revisaron un total de 102 lenguados, 33 en Todos Santos, 31 en Punta Banda y 38 en San Quintín.

Para cada uno de los lenguados se registró la longitud estándar (en milímetros), el peso (en gramos) y el sexo. La revisión consistió de un examen externo y uno interno. En el primer caso se analizaron las aletas, las branquias y la supcrficie del cuerpo; en el segundo, se realizó la disección de los peces, separando los órganos y revisando bajo un microscopio estereoscópico la cavidad corporal, vejiga natatoria, esófago, estómago, ciegos intestinales, riñones, hígado y una parte del músculo, estos últimos comprimiéndolos entre dos vidrios.

Los helmintos fueron contados in situ y se fijaron y procesaron de acuerdo con técnicas particulares para cada grupo. Los trematodos y cestodos se relajaron en agua caliente, aplanándolos posteriormente entre porta y cubreobjetos, utilizando el fijador líquido de Bouin entre 12 y $24 \mathrm{~h}$. Los nematodos se relajaron con alcohol etílico al $70 \%$. Los acantocéfalos se introdujeron en agua destilada en refrigeración durante $12 \mathrm{~h}$ para volver la probóscide hacia afuera. Los platelmintos y los acantocéfalos se tiñeron con paracarmin de Mayer, hematoxilina de Fhrlich y tricrómica de Gomori; se aclararon con salicilato de metilo y se montaron en preparaciones permanentes con bálsamo de Canadá. Los nematodos se aclararon con lactofenol y se montaron en preparaciones semipermanentes.

De cada una de las especies se elaboraron esquemas con ayuda de una cámara lúcida y se midieron utilizando un ocular micrométrico calibrado con precisión de $0.001 \mathrm{~mm}$. La caracterización de las infecciones causadas por cada una de description of the fishing gear is found in RosalesCasian (1996). A total of 102 halibut were examined, 33 from Todos Santos, 31 from Punta Banda and 38 from San Quintín.

The standard length (in millimeters), weight (in grams) and the sex of each halibut were recorded. Both external and internal examinations were made. The external examination consisted of analyzing the fins, branchiae and body surface, and the internal examination of dissecting the fish and separating the organs. A stereoscopic microscope was used to examine the corporal cavity, air bladder, esophagus, stomach, caecum, kidneys, liver and part of the muscle, which were compressed between two slides.

The helminths were counted in situ and were fixed and processed according to the particular techniques of each group. The trematodes and cestodes were relaxed in hot water, and were later flattened for 12-24 h between two slides using Bouin's solution as fixative. The nematodes were relaxed in $70 \%$ ethyl alcohol. The acanthocephalans were refrigerated in distilled water for $12 \mathrm{~h}$, so that the proboscis would evert. The platyhelminths and the acanthocephalans were stained with Mayer's paracarmine, Ehrlich's hematoxylin and Gomori's trichrome; they were cleared with methyl salicylate and were mounted in permanent preparations with Canada balsam. The nematodes were cleared with lactophenol and were mounted in semi-permanent preparations.

Drawings of each species were made with a camera lucida. They were measured with a micrometric ocular of $0.001 \mathrm{~mm}$ precision. The infections caused by each of the helminth species were characterized using the attributes proposed by Margolis et al. (1982). Prevalence is the percentage of hosts infected by a particular parasite species and abundance is the average number of individuals of a particular parasite species per host analyzed.

The specimens of each species were deposited in the National Helminth Collection (CNHE) of the Institute of Biology of the Universidad Nacional Autónoma de México. 
las especies de helmintos se obtuvo utilizando los atributos propuestos por Margolis et al. (1982). La prevalencia es el porcentaje de hospedantes infectados por una especie particular de parásito y la abundancia es el número promedio de individuos de una especie particular de parásito por hospedante revisado en la muestra.

Los ejemplares de cada una de las especies fueron depositados en la Colección Nacional de Helmintos (CNHE) del Instituto de Biología de la Universidad Nacional Autónoma de México.

\section{RESULTADOS}

El registro helmintológico de $P$. californicus en los sitios de estudio fue de 14 especies. El grupo de los trematodos estuvo representado por seis especies: Metadena magdalenae Arai, 1962; Opegaster parapristipomatis Yamaguti, 1934; Parahemiurus merus (Linton, 1910) Manter, 1940; Stephanostomum dentatum (Linton, 1900) Manter, 1931; Tubulovesicula lindbergi (Layman, 1930) Yamaguti, 1934; y una especie de la subfamilia Cryptogoniminac. Los nematodos presentaron un número de especies similar, tres en estado de larva: Anisakis sp., Contracaecum sp. y Porrocaecum sp; y tres en estado adulto: Philometra sp., Spirocamallanus pereirai (Annereaux, 1943) Olsen, 1952 e Hysterothylacium sp. Los cestodos y los acantocéfalos estuvieron representados con una especie cada uno, los primeros por los plerocercos del orden Tetraphyllidea Carus, 1863 y los últimos por los cistacantos de la especie Corynosoma strumosum Rudolphi, 1802 (tabla 1).

El órgano más parasitado por los helmintos en este lenguado fue el tubo digestivo, donde se encontraron 11 de las 14 especies que fueron registradas. Los trematodos y cestodos se encontraron exclusivamente en el tubo digestivo, principalmente en el estómago, en tanto que los acantocéfalos se localizaron exclusivamente en el mesenterio. Los nematodos se encontraron parasitando el mayor número de partes dentro del hospedante, sobre todo las larvas de la subfamilia Anisakinac; éstas son migratorias con capacidad

\section{RESULTS}

The helminthological record of $P$. californicus at the study sites consisted of 14 species. The trematodes were represented by six species: Metadena magdalenae Arai, 1962; Opegaster parapristipomatis Yamaguti, 1934; Parahemiurus merus (Linton, 1910) Manter, 1940; Stephanostomum dentatum (Linton, 1900) Manter, 1931; Tubulovesicula lindbergi (Layman, 1930) Yamaguti, 1934; and one species of the subfamily Cryptogoniminae. The nematodes presented a similar number of species, three in the larval stage: Anisakis sp., Contracaecum sp. and Porrocaecum sp.; and three in the adult stage: Philometra sp., Spirocamallanus pereirai (Annereaux, 1943) Olsen, 1952 and Hysterothylacium $\mathrm{sp}$. The cestodes and the acanthocephalans were represented by one species each, the former by plerocercoids of the order Tetraphyllidae Carus, 1863 and the latter by the cystacanths of the species Corynosoma strumosum Rudolphi, 1802 (table 1).

The halibut organ most infested by the helminths was the digestive tract, where 11 of the 14 species recorded occurred. The trematodes and cestodes occurred exclusively in the digestive tract, mainly the stomach, while the acanthocephalans occurred exclusively in the mesentery. The nematodes occurred in the most parts within the host, especially larvae of the subfamily Anisakinae; they are migratory and are able to penetrate the tissue until reaching the corporal cavity and infecting the viscera and muscle of the fish. They can also encyst, which allows them to survive anywhere within the host and counteract its immune response.

Of the 14 species that make up the helminthological record, only six occurred in all three sample sites ( $M$. magdalenae, $T$. lindbergi, Tetraphyllidea, C. strumosum, Anisakis sp. and Contracaecum sp.). Five occurred exclusively at one of the sites (Cryptogoniminae, $O$. parapristipomatis, S. pereirai, Hysterothylacium sp. and Philometra sp.); whereas, P. merus, $S$. dentatum and Porrocaecum sp. larvae occurred at two sites, 
Tabla 1. Registro helmintológico de Paralichthys californicus en tres sitios de Baja California, México: Bahía de Todos Santos (BTS), Estero de Punta Banda (EPB) y Bahía de San Quintín (BSQ). $\mathrm{E}=$ estómago, $\mathrm{I}=$ intestino, $\mathrm{CI}=$ ciegos intestinales, $\mathrm{M}=$ mesenterio, $\mathrm{H}=$ higado, $\mathrm{G}=$ gónadas.

Table 1. Helminthological record of Paralichthys californicus for three sites of Baja California, Mexico. Todos Santos Bay (BTS), Estero de Punta Banda (EPB) and San Quintín Bay (BSQ). E = stomach, I = intestine, $\mathrm{CI}=$ caecum, $\mathrm{M}=$ mesentery, $\mathrm{H}=$ liver, $\mathrm{G}=$ gonads.

\begin{tabular}{|c|c|c|c|}
\hline Helmintos & BTS & EPB & BSQ \\
\hline \multicolumn{4}{|l|}{ Trematoda } \\
\hline \multicolumn{4}{|l|}{ Digenea } \\
\hline Cryptogoniminae & & & $\mathrm{I}, \mathrm{E}$ \\
\hline Metadena magdalenae & $\mathrm{E}, \mathrm{I}$ & $\mathrm{E}$ & $E, I$ \\
\hline Opegaster parapristipomatis & $\mathrm{E}$ & & \\
\hline Parahemiurus merus & $\mathrm{E}$ & $\mathrm{E}$ & \\
\hline Stephanostomum dentatum & . & E, I & $\mathrm{E}$ \\
\hline Tubulovesicula lindbergi & $\mathrm{E}$ & $\mathrm{E}$ & $\mathrm{E}$ \\
\hline \multicolumn{4}{|l|}{ Cestoda } \\
\hline Tetraphyllidea & $\mathrm{I}, \mathrm{CI}, \mathrm{E}$ & $\mathrm{I}, \mathrm{CI}, \mathrm{E}$ & $E$ \\
\hline \multicolumn{4}{|l|}{ Acanthocephala } \\
\hline Corynosoma strumosum & M & M & M \\
\hline \multicolumn{4}{|l|}{ Nematoda } \\
\hline Anisakis sp. & M & $\mathrm{M}, \mathrm{I}, \mathrm{H}, \mathrm{G}$ & $\mathrm{M}, \mathrm{E}, \mathrm{I}$ \\
\hline Contracaecum sp. & M, E, I & M, I & M, I \\
\hline Porrocaecum sp. & M & & $\mathrm{E}, \mathrm{M}$ \\
\hline Spirocamallanus pereirai & & I & \\
\hline Hysterotylacium $\mathrm{sp}$. & & & M \\
\hline Philometra sp. & & $\mathrm{M}$ & \\
\hline
\end{tabular}

de penetrar los tejidos hasta llegar a la cavidad corporal e infectar las vísceras y músculo del pez. Además, tienen la capacidad de enquistarse, lo que les permite sobrevivir en cualquier sitio dentro del mismo y contrarrestar la respuesta inmune del hospedante.

De las 14 especies que componen el registro helmintológico, sólo seis se encontraron compartiendo las tres áreas muestreadas (M. magdalenae, the former at Todos Santos Bay and Estero de Punta Banda and the latter two at Estero de Punta Banda and San Quintín Bay (table 1).

Below is the information on the helminth species found in $P$. californicus. It provides the morphological traits that characterize and differentiate them from other congeneric species, as well as data on their geographic distribution and the host they previously parasitized. 
T. lindbergi, Tetraphyllidea, C. strumosum, Anisakis sp. y Contracaecum sp.). Cinco se distribuyeron exclusivamente en una de las tres zonas (Cryptogoniminae, $O$. parapristipomatis, $S$. pereirai, Hysterothylacium sp. y Philometra sp.), mientras que $P$. merus, $S$. dentatum y las larvas de Porrocaecum sp. se encontraron en dos localidades, la primera en la Bahía de Todos Santos y el Estero de Punta Banda, la segunda y la última en el Estero de Punta Banda y la Bahía de San Quintín (tabla 1).

A continuación se presenta información de las especies de helmintos que parasitan a $P$. californicus, señalando aquellos rasgos morfológicos que las diagnostican y diferencian de otras especies congenéricas, así como datos sobre su distribución geográfica $y$ hospedante a los que previamente parasitan.

\section{Trematoda}

\section{Digenea}

Acantocolpidae Lühe, 1909

Stephanostomum dentatum (Linton, 1900)

Manter, 1931

La especie tipo de este género es $S$. cesticillum (Molin, 1858) Looss, 1899. En este estudio, los ejemplares recolectados en el estómago e intestino de $P$. californicus, capturados en el Estero de Punta Banda y Bahía de San Quintín, correspondieron a la especie $S$. dentatum (tabla 1 ). Esta especie fue identificada por la distribución continua de las vitelógenas, gónadas contiguas, el número de espinas orales (48-52) y el tamaño de los huevos. CNHE: 2899-2901.

Cryptogonimidae (Ward, 1917) Ciurea, 1933 Metadena magdalenae Arai, 1962

Dentro del género Metadena se incluyen ocho especies; $M$. magdalenae ha sido registrada sólo en $P$. californicus de la zona costera de Baja California, por lo que el hospedante y la localidad se consideran típicas de la especie. Los ejemplares localizados en el estómago fueron de lenguados

\section{Trematoda \\ Digenea}

Acantocolpidae Lühe, 1909

Stephanostomum dentatum (Linton, 1900)

Manter, 1931

The type species of this genus is S. cesticillum (Molin, 1858) Looss, 1899. The specimens collected from the stomach and intestine of $P$. californicus at Estero de Punta Banda and San Quintín Bay corresponded to $S$. dentatum (table 1). This species was identified by the continuous distribution of the vitellaria, the contiguous gonads, the number of oral spines (48-52) and the size of the eggs. CNHE: 2899-2901.

Cryptogonimidae (Ward, 1917) Ciurea, 1933

Metadena magdalenae Arai, 1962

There are eight species that make up the genus Metadena; $M$. magdalenae has been found only in P. californicus on the coast of Baja California and, therefore, the host and site are considered typical for the species. The specimens that occurred in the stomach were from halibut caught at the three sites, and the parasites collected from the intestine were from halibut caught at only two sites (table 1). They were identified as M. magdalenae because their sucker ratio (1:4.8) was similar to that reported $(1: 4.5)$ by Arai (1962), and because of the distribution and location of the vitellaria, the length of the caecum and because they did not present spines on the body. The species of the family Cryptogonimidae are digenous parasites of the digestive tract of marine and fresh-water fish, as well as reptiles. Their life cycle is well known (Yamaguti, 1975). CNHE: 2888-2892.

Opecoelidae Ozaki, 1925

Opegaster parapristipomatis Yamaguti, 1938

This species was previously recorded as a parasite of Parapristipoma trilineatum from Japan, Trachinotus rhodopus from the Galapagos 
capturados en los tres lugares y aquellos parásitos que se recolectaron en el intestino fucron de individuos capturados en sólo dos lugares (tabla 1). Se identificaron como $M$. magdalenae por concordar con la proporción de las ventosas $(1: 4.8)$ de un reporte (1:4.5) de Arai (1962), por la distribución y localización de las vitelógenas, la longitud de los ciegos intestinales y por no presentar espinas en el cuerpo. Las especies de la familia Cryptogonimidae son digéneos parásitos del tuho digestivo de peces marinos y de agua dulce, así como reptiles. Su ciclo de vida es muy conocido (Yamaguti, 1975). CNI IL: 2888-2892.

Opecoelidae Ozaki, 1925

Opegaster parapristipomatis Yamaguti, 1938

Esta especie ha sido registrada previamente parasitando a Parapristipoma trilineatum en Japón. Trachinotus rhodopus en las islas Galápagos y Selar crumenophthalmus en Panamá (Yamaguti, 1971). Opegaster parapristipomatis se registró en el estómago de $P$. californicus en la Bahía de Todos Santos (tabla 1). Fue asignada a esta especie por la distribución de las vitelógenas, la posición del poro genital, el número de papilas acetabulares y la localización de las gónadas, así como por coincidir con las descripciones previas para esta especie. CNHE: 2895.

Hemiuridae (Looss, 1899) Lühe, 1901

Parahemiurus merus (Linton, 1910) Manter, 1940)

Parahemiurus merus fue localizada en el estómago de lenguados de California recolectados en la Bahía de Todos Santos y el Estero de Punta Banda (tabla 1). Corresponde a la especie tipo de este género, descrita como párasito de Cuplanodon pseudohispanicus en Tortugas, Florida. Muchas de las especies asignadas a este género corresponden a sinonimias de $P$. merus (Bray, 1990). Se ha registrado previamente por León-Regagnon et al. (1997a, b) y LamotheArgumedo et al. (1997) en la Bahía de Chamela (Jalisco) y Bahía de Todos Santos, respectivamente. Una revisión para este género (Bray, 1990)
Islands and Selar crumenophthalmus from Panama (Yamaguti, 1971). Opegaster parapristipomatis was found in the stomach of $P$. californicus from Todos Santos Bay (table 1). It was identified by the distribution of the vitellaria, the position of the genital pore, number of acetabular papilla and the location of the gonads, and because it concurred with previous descriptions for this species. CNHE: 2895.

Hemiuridae (Looss, 1899) l,ühe, 1901

Parahemiurus merus (Linton, 1910) Manter, 1940

The species $P$. merus occurred in the stomach of California halibut from Todos Santos Bay and Estero de Punta Banda (table 1). It is the type species of this genus, described as a parasite of Cuplanodon pseudohispanicus from Tortugas, Florida. Many of the species assigned to this genus correspond to synonymies of $P$. merus (Bray, 1990). It has been previously recorded by León-Regagnon et al. (1997a, b) and LamotheArgumedo et al. (1997) at Chamela Bay (Jalisco) and Todos Santos Bay, respectively. A review of this genus (Bray, 1990) provided the morphological characteristics for separating the species: the cuticle folds, the size of the eggs, the length of the sinus sac. the length:width ratio between the suckers and the shape of the seminal vesicle. Based on this, only seven nominal species are considered, of which P. merus has the greatest number of synonymies. CNHE: 2893 and 2894.

Tubulovesicula lindbergi (Layman, 1930) Yamaguti, 1934

Tubulovesicula lindbergi represents the type species of this genus and was located only in the stomach of the halibut caught at the three sites (table 1). Sogandares-Bernal (1959) recognizes four species in this genus and distinguishes $T$. lindbergi by the position of the ovary and the testicles, as well as the distribution of the uterus, position and size of the vitellaria and shape and position of the seminal vesicle. This species 
sugirió las características morfológicas para separar las especies: los pliegues de la cutícula, el tamaño de los huevos, la longitud del sinus sac, la proporción de largo y ancho entre sus ventosas y la forma de la vesícula seminal. Con base en esto, sólo siete especies se consideran nominales, de las que $P$. merus tiene el mayor número de sinonimias. CNHE: 2893 y 2894.

Tubulovesicula lindbergi (Layman, 1930) Yamaguti, 1934

Tubulovesicula linabergi representa a la especie tipo de este género y se localizó sólo en el estómago de lenguados capturados en los tres sitios (tabla 1). Sogandares-Bernal (1959) considera cuatro especies en este género y distingue a $T$. lindbergi por la posición del ovario y los testículos, así como la distribución del útero, posición y tamaño de las vitelógenas y forma y posición de la vesícula seminal. Esta especie parasita muchos peces pelágicos y demersales, principalmente de los Pleuronectidae (Bray, 1990). CNHE: 2896-2898.

\section{Cestoda}

Tetraphyllidea Carus, 1863

Estos cestodos se identificaron a este nivel porque sólo se registraron como larvas en el estómago, ciegos intestinales e intestino de los lenguados recolectados en Todos Santos y Punta Banda, y en el estómago de aquellos de San Quintín (tabla 1). Por la morfología y disposición de los cuatro botridios sésiles que forman el escólex de estas larvas, se les incorporó al orden Tetraphyllidea (Euzet, 1994).

\section{Acanthocephala}

Polymorphidae Meyer, 1931

Corynosoma strumosum Rudolphi, 1802

Corynosoma strumosum se encontró exclusivamente en el mesenterio de lenguados que se parasitizes many pelagic and demersal fish, mainly Pleuronectidae (Bray, 1990). CNHE: 2896-2898.

\section{Cestoda}

Tetraphyllidea Carus, 1863

These cestodes were identified to this level because they were recorded only as larvae in the stomach, caecum and intestine of the halibut collected from Todos Santos and Punta Banda, and in the stomach of those from San Quintin (table 1). They were incorporated into the order Tetraphyllidea (Euzet, 1994) because of the morphology and disposition of the four sessile bothria that form the scolex of these larvae.

\section{Acanthocephala}

Polymorphidae Meyer, 1931

Corynosoma strumosum Rudolphi, 1802

Corynosoma strumosum was found only in the mesentery of the halibut collected at the three study sites (table 1). This is the first record of $C$. strumosum juveniles in intermediate or paratenic hosts (fish). They were identified based on the pattern of the spines on the body and on the hooks of the proboscis and by the size of the organisms. CNHE: 2902-2904.

\section{Nematoda}

Anisakidae Hartwich, 1974

Anisakinae Railliet and Henry, 1912

Larvae of the anisakid nematodes were found in different organs (mesentery, stomach, intestine, liver) of $P$. californicus (table 1) and they were assigned to the three most common genera of this family, based on the characteristics of the digestive tract, position of the excretory pore opening and structures of the cephalic region. These genera are: Anisakis Dujardin, 1845 (CNHE: 2905-2907); Contracaecum Railliet and Henry, 
recolectaron en los tres sitios de estudio (tabla 1). Éste constituye el primer registro de formas juveniles de C. strumosum en hospedantes intermediarios o paraténicos (peces). Se identificaron con base en el patrón de espinación en el cuerpo y en los ganchos de la probóscide y por el tamaño de los organismos. CNHE: 2902-2904.

\section{Nematoda}

Anisakidae Hartwich, 1974

Anisakinae Railliet y Henry, 1912

Las larvas de nematodos anisákidos fueron encontradas en diferentes órganos (mesenterio, estómago, intestino, hígado) de $P$. californicus (tabla 1), y se asignaron a los tres géneros más comunes de esta familia con base en las características del tubo digestivo, posición de la abertura del poro excretor y estructuras de la región cefálica. I. ichos géneros son: Anisakis Dujardin, 1845 (CNHE: 2905-2907); Contracaecum Railliet y Henry, 1912 (CNHE: 2908-2910); y Porrocaecum Railliet y Ilenry, 1912 (= Pseudoterranova Mozgovoy, 1950 = Phocanema, Myers, 1959) (CNHE: 2911). Se consideró la presencia de tres géneros por las siguientes características: el género Anisakis por la presencia de un ventrículo, por no presentar interlabios y por tener la abertura del poro excretor a nivel del anillo nervioso; el género Contracaecum por presentar un ciego intestinal y un apéndice ventricular, además de interlabios en la región oral; el género Porrocaecum presenta el poro excretor en la misma posición que el género Anisakis, sólo que este último posee un ciego intestinal (Myers, 1975; Olson et al., 1983). En estadio adulto estos nematodos son parásitos de reptiles, aves y mamiferos piscívoros; como larvas parasitan gran cantidad de teleósteos marinos e invertebrados (pelecípodos, crustáceos y cefalópodos), mismos que al ser consumidos por el hombre, ya sea crudos o semicocidos, pueden llegar a desarrollar la enfermedad denominada Anisakiasis (Sakanari, 1990).
1912 (CNHE: 2908-2910); and Porrocaecum Railliet and Ilenry, 1912 (= Pseudoterrunova Mozgovoy, $1950=$ Phocanema, Myers, 1959) (CNHE: 2911). The occurrence of the three genera was based on the following characteristics: the genus Anisakis, by the presence of a ventricle, but no interlabia and by having the excretory pore opening at the level of the nerve ring; the genus Contracaecum by presenting a caecum and ventricular appendage, as well as interlabia around the mouth; the genus Porrocaecum by presenting the excretory pore in the same position as the genus Anisakis, but having a caecum (Myers, 1975; Olson et al., 1983). In the adult stage, these nematodes parasitize reptiles, birds and piscivorous mammals; as larvae, they infest a wide variety of marine teleosts and invertebrates (pelecypods, crustaceans and cephalopods), which when consumed by man, either raw or semicooked, can cause anisakiasis disease (Sakanari, 1990).

Raphidascaridinae Hartwich, 1954 Ilysterothylacium Ward and Magath, $1917=$ Thynnascaris Dollfus, 1933

This genus was located in the mesentery of the halibut collected exclusively at San Quintin Bay (table 1). Its larval forms are mistaken for those of the genus Contracaecum; however, as adults Hysterothylacium parasitize fish, and Contracaecum mature in birds and mammals (Norris and Overstreet, 1975). It has been found as larvae and adults in many marine and freshwater teleosts around the world. The taxonomy of the species of this genus is not resolved, due to the many synonymies assigned to them because of the characteristics they share with other genera of the family Anisakidae (Contracaecum, Ascaris, Thynnascaris, etc.). Deardorff and Overstreet (1981) consider Hysterothylacium a taxonomically valid genus, and $H$. aduncun (Rudolphi, 1802 ) as the only species, because it has the greatest distribution in fish and invertebrates (Marcogliese, 1996). CNHE: 2912. 
Raphidascaridinae Hartwich. 1954

Hysterothylacium Ward y Magath, $1917=$

Thynnascaris Dollfus. 1933

Este género se localizó en el mesenterio de lenguados recolectados exclusivamente en la Bahía de San Quintín (tabla 1). Sus formas larvarias son confundidas con las del género Contracaecum; sin embargo, como adulto Hysterothylacium parasita a peces, mientras que Contracaecum madura en aves y mamíferos (Norris y Overstreet, 1975). Se ha registrado como larva y adulto en muchos teleósteos marinos y dulceacuícolas del mundo. La taxonomia de las especies de este género no está resuelta, ya que se le asignan muchos sinónimos por compartir características con otros géneros de la familia Anisakidae (Contracaecum. Ascaris, Thynnascaris, etc.). Deardorff y Overstreet (1981) consideran como género taxonómicamente válido a Hysterothylacium, e incluso como única especie a H. aduncun (Rudolphi, 1802) por presentar la mayor distribución en peces e invertebrados (Marcogliese, 1996). CNHE: 2912.

Camallanidae Railliet y Henry, 1915

Spirocamallanus pereirai (Annereaux, 1946)

Olsen, 1952

Estos nematodos fueron localizados en el intestino de lenguados recolectados sólo en el Estero de Punta Banda (tabla 1). Se asignaron a la especie $S$. pereirai por coincidir con las descripciones de esta especie de nematodo en peces del norte de California (EUA), como Atherinopsis californiensis, Leptocottus armatus, Fundulus parvipinnis, Atherinops affinis, Girella nigricans, Gillichthys mirabilis y $P$. californicus del sur de California (Love y Moser, 1983). El género Spirocamallanus inicialmente se incluyó dentro de Procamallanus, designado para todas las especies con una cápsula bucal en forma de barril. Sin embargo, Olsen (1952) separó a Spirocamallanus por presentar espirales en la cápsula bucal e incluyó a 16 especies, entre ellas a $S$. pereirai.
Camallanidae Railliet and Henry, 1915

Spirocamallanus pereirai (Annereaux, 1946)

Olsen, 1952

These nematodes were located in the intestines of halibut collected only at Estero de Punta Banda (tahle 1). They were assigned to the species $S$ pereirai because they concurred with the descriptions of this nematode species in fish of northern California (USA), such as Atherinopsis californiensis, Leptocottus armatus, Fundulus parvipinnis, Atherinops affinis, Girella nigricans, Gillichthys mirabilis and $P$. californicus from southern California (Love and Moser, 1983). The genus Spirocamallanus was initially included in Procamallanus, designating all the species with a barrel-shaped bucal capsule. However, Olsen (1952) separated Spirocamallanus because it presented spirals in the bucal capsule and included 16 species, among them $S$, pereirai. This species has been recorded only in marinc fish, although other congeneric species have been recorded in fresh-water fish from Mexico (Andrade-Salas et al., 1994). CNHF: 2914.

Philometridae Baylis and Daubney, 1926 Philometra Costa, 1845

This genus was found only in the mesentery of individuals collected at Estero de Punta Banda (table 1). It was not possible to determine the specific level, because only one adult specimen was found, a nongravid female. The specimen was assigned to this genus, because the upper part of the esophagus was bulbous shaped, it had papilla in the cephalic region and an attenuated lower end. Members of the family Philometridae exclusively parasitize marine and fresh-water fish. Some 50 species from all over the world have been included in the genus Philometra. The type species of this genus is Philometra (Philometra) globiceps Rudolphi, 1819 (Rasheed, 1963). The females tend to change when gravid, causing controversy in their taxonomy. CNHE: 2913. 
Esta especie ha sido registrada sólo en peces marinos, aunque otras especies congenéricas se han registrado en peces dulceacuícolas de México (Andrade-Salas et al., 1994). CNHE: 2914.

Philometridae Baylis y Daubney, 1926

Philometra Costa, 1845

Este género se localizó sólo en el mesenterio de individuos recolectados en el Estero de Punta Banda (tabla 1). En nuestro caso no se logró la determinación a nivel específico, ya que sólo se contó con un ejemplar adulto, hembra no grávida. El ejemplar fue asignado a este género por presentar la parte anterior del esófago en forma bulbosa, papilas en la región cefálica y el extremo posterior atenuado. Los miembros de la familia Philometridae son exclusivamente parásitos de peces marinos y de agua dulce. Unas 50 especies se han incluido en el género Philometra procedentes de todas partes del mundo. Este género tiene como especie tipo a Philometra (Philometra) globiceps Rudolphi, 1819 (Rasheed, 1963). Las hembras suelen modificar sus caracteres cuando están grávidas, ocasionado controversia en su taxonomía. CNHE: 2913.

\section{Caracterización de las helmintiasis}

En los cuatro muestreos realizados en los sitios de estudio se revisaron un total de 102 lenguados, obteniéndose 919 helmintos pertenecientes a cuatro grupos: Trematoda, Cestoda, Acanthocephala y Nematoda. El grupo más abundante lo constituyeron los cestodos con 356 individuos $(38.8 \%)$, siguiéndole en orden de abundancia los nematodos con 337 (36.7\%), trematodos con $199(21.7 \%)$ y acantocéfalos con $27(3.0 \%)$.

La caracterización de cada una de las infecciones causadas por helmintos en $P$. californicus se realizó para cada una de las zonas muestreadas (fig. 2), tomando en cuenta los parámetros propuestos por Margolis et al. (1982). Se encontró que tanto en el Estero de Punta Banda como en la Bahía de Todos Santos, la mayor abundancia tue

\section{Characterization of the helminths}

In the four samplings conducted at the study sites, a total of 102 halibut were examined, and 919 helminths were obtained, pertaining to four groups: Trematoda, Cestoda, Acanthocephala and Nematoda. The most abundant group was the cestodes, with 356 specimens $(38.8 \%)$, followed in order of abundance by the nematodes with 337 (36.7\%), trematodes with $199(21.7 \%)$ and acanthocephalans with $27(3.0 \%)$.

The characterization of each of the infections caused by the helminths in $P$. californicus was made for each of the sampling sites (tig. 2), taking into account the parameters proposed by Margolis et al. (1982). The highest abundance was observed in Estero de Punta Banda and Todos Santos Bay for the plerocercoids of the order Tetraphyllidea (6.06 and 4.03 parasites per fish analyzed, respectively), whereas in San Quintín Bay, the most abundant helminth was Anisakis sp. (5.92), followed in order of importance by the digenetic trematode $M$. magdalenae. The remaining species at the three sites occurred in relatively low abundance (between 0.03 and 2.6).

With regard to the prevalence of infection, at Todos Santos Bay and San Quintín Bay, the helminth that obtained the highest values corresponds to Anisakis larvae, which parasitized 39.4 to $60.5 \%$ of the fish analyzed, respectively. The other species did not present prevalence values higher than $30 \%$ in the three study areas, indicating that their occurrence in this host is not very common (fig. 2).

\section{DISCUSSION}

In the 102 fish analyzed, 14 species of helminths were found. The trematodes and nematodes were the best represented groups, with six species each. For $93 \%$ of the helminth species recorded, Todos Santos Bay, Estero de Punta Banda and San Quintín Bay represent new site records, whereas for $50 \%$ of them, $P$. californicus is a new host record. The absence of monogeneans is noteworthy, since at least Entobdella 
a)

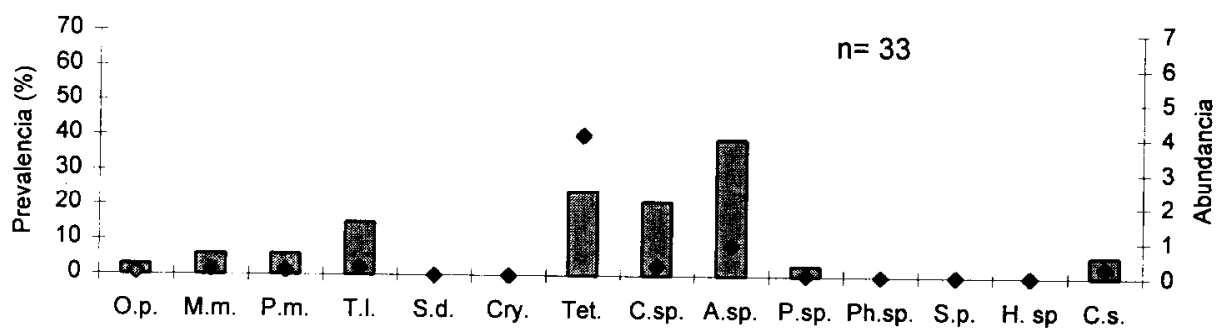

Especies de Helmintos

b)

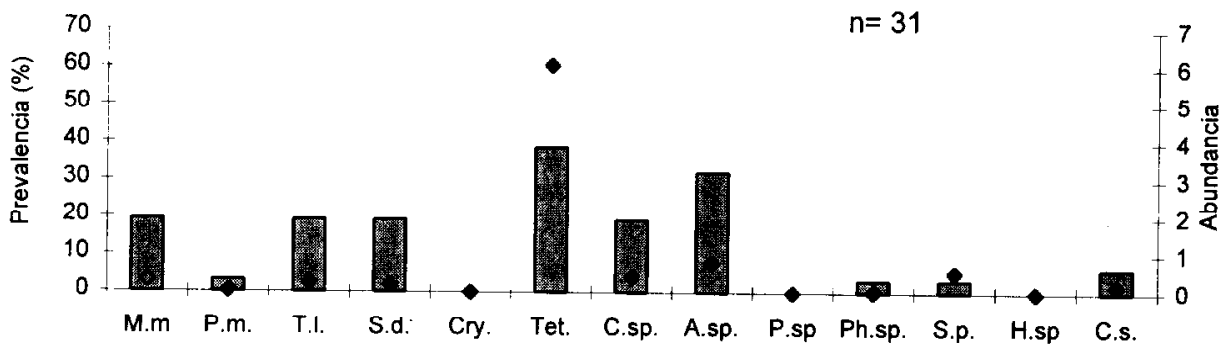

Especies de Helmintos

c)

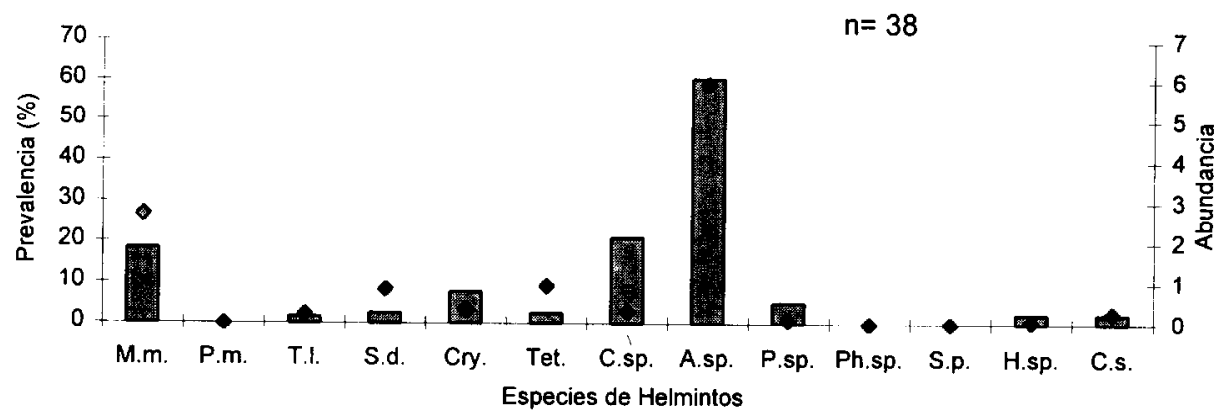

Figura 2. Prevalencia $(\square)$ y abundancia $(\bullet)$ de las especies de helmintos parásitos de Paralichthys californicus en (a) Bahía de Todos Santos, (b) Estero de Punta Banda y (c) Bahía de San Quintín, Baja California, México. O.p., Opegaster parapristipomatis; M.m., Metadena magdalenae; P.m., Parahemiurus merus; T.I., Tubulovesicula lindbergi; S.d., Stephanostomum dentatum; Cry., Cryptogoniminae; 'Tet., Tetraphyllidea; C.sp., Contracaecum sp.; A.sp., Anisakis sp.; P.sp., Porrocaecum sp.; Ph.sp., Philometra sp.; S.p., Spirocallamus pereirai; H.sp., Hysterotylacium sp.; C.s., Corynosoma strumosum.

Figure 2. Prevalence $(\square)$ and abundance $(\checkmark)$ of the helminth parasite species of Paralichthys californicus in (a) Todos Santos Bay, (b) Estero de Punta Banda and (c) San Quintín Bay, Baja California, Mexico. O.p., Opegaster parapristipomatis; M.m., Metadena magdalenae; P.m., Parahemiurus merus; T.l., Tubulovesicula lindbergi; S.d., Stephanostomum dentatum; Cry., Cryptogoniminae; Tet., Tetraphyllidea; C.sp., Contracaecum sp.; A.sp., Anisakis sp.; P.sp., Porrocaecum sp.; Ph.sp., Philometra sp.; S.p., Spirocallamus pereirai; H.sp., Hysterotylacium sp.; C.s., Corynosoma strumosum. 
alcanzada por los plerocercos del orden Tetraphyllidea ( 6.06 y 4.03 parásitos por pez analizado, respectivamente), mientras que en la Bahía de San Quintin. el helminto más abundante fue Anisakis sp. (con 5.92), siguiéndole en orden de importancia el trematodo digenético $M$. magdalenae. Las especies restantes en las tres localidades se encuentran distribuidas con abundancias relativamente bajas (entre 0.03 y 2.6 ).

Con respecto a la prevalencia de la infección, cabe señalar que en la Bahía de Todos Santos y en la Bahía de San Quintín el helminto que registró los valores más altos corresponde a las larvas de Anisakis, que parasitaron un $39.4 \%$ y $60.5 \%$ de los peces analizados, respectivamente. Las otras especies no alcanzaron valores de prevalencia mayores que $30 \%$ en las tres zonas de muestreo, lo cual implica que su presencia en este hospedante es poco común (fig. 2).

\section{DISCUSIÓN}

En los 102 peces analizados se encontraron 14 especies de helmintos, siendo los grupos mejor representados los trematodos y nematodos, con seis especies cada uno. Para el $93 \%$ de las especies de helmintos registrados, la Bahia de Iodos Santos, el Estero de Punta Banda y la Bahía de San Quintín representan nuevos registros de localidad, mientras que para el $50 \%$ de éstos, $P$. californicus es nuevo registro de hospedante. Resalta la ausencia de monogéneos, pues al menos Entobdella squamula habia sido registrada como parásito del lenguado de California (Love y Moser, 1983).

Los hábitos alimenticios de los hospedantes son uno de los principales factores que determinan su fauna parasitaria (Dogiel, 1964). Los helmintos que parasitan a $P$. californicus son incorporados por medio de la ingestión de formas larvarias libres en el plancton o presentes en hospedantes intermediarios o paraténicos. De acuerdo con estudios realizados sobre los hábitos alimenticios de este pez, la presencia de las especies de helmintos encontrados debe ser común (Roberts et al., 1981; Kramer, 1991), ya que los squamula had previously been recorded as a parasite of the California halibut (Love and Moser, 1983).

The feeding habits of the hosts are one of the main factors that determine their parasitic fauna (Dogiel, 1964). The helminths that parasitize $P$. californicus are incorporated through ingestion of free larval forms in the plankton or those present in intermediate or paratenic hosts. According to studies on the feeding hahits of this fish, the occurrence of the helminth species found is common (Roberts et al., 1981; Kramer, 1991), since halibut coexist with intermediate hosts and infectious stages within their habitat.

The trematodes were important in the helminth richness exhibited in $P$. callfornicus, which concurs with the biodiversity patterns exhibited by this group of parasites in marine fish (Manter, 1940; Overstreet, 1969). Most of the infections by trematodes are acquired through consuming prey that form part of the fish's diet and that are intermediate hosts for the metacercaria stage (Yamaguti, 1975). A not very common result obtaincd in this study is the great richness presented by the nematodes, a generally less diverse group in marine fish. Furthermore, three of the species $(50 \%)$ identified to genus were larval forms, which makes $P$. californicus an important host for the transmission dynamics of helminths, such as marine mammals like Anisakis sp., fish like Hysterothylacium sp. and birds like Contracaecum sp. (Anderson, 1992). It should be noted that it is not possible to determine the specific level, given the larval nature of the specimens.

The digenean $S$. dentatum found in the stomach and intestines of the halibut is widely distributed in marine fish, since it parasitizes the halibut Paralichthys dentatus of Woods Hole, Massachusetts (Linton, 1905) and P. albiguttatus of Beaufort, Florida (Manter, 1947). It has been reported in the intestines of $P$. californicus in La Jolla, California (Manter and Van Cleave, 1951), of Dassycottus setiger in British Colombia (Arai, 1969), of Embiotoca jacksoni in Baja California (Arai, 1961) and of Sebastes aleutianus, $S$. 
lenguados coexisten con hospedantes intermediarios y estados infectivos dentro del hábitat que ocupan.

Los trematodos fueron importantes en la riqueza de helmintos exhibida en $P$. californicus, lo cual resulta congruente con los patrones de biodiversidad exhibidos por este grupo de parásitos en peces marinos (Manter, 1940; Overstreet, 1969). La mayor parte de las infecciones por trematodos son adquiridas a través del consumo de presas que forman parte de la dieta del pez y que son hospedantes intermediarios que albergan al eslado de melacercaria (Yamaguti, 1975). Lo que resulta poco común en nuestros resultados es la gran riqueza que presentaron los nematodos, grupo generalmente menos diverso en peces marinos. También es interesante que tres de las especies $(50 \%)$ identificadas hasta género fueron formas larvarias, lo que convierte a $P$. californicus en un hospedante importante para la dinámica de transmisión de helmintos, ya sea a mamíferos marinos como Anisakis sp., a peces como Hysterothylacium sp., y a aves como Contracaecum sp. (Anderson, 1992). Cabe señalar que la determinación a nivel específico no es posible dada la naturaleza larvaria de los especímenes.

El digénido $S$. dentatum encontrado en el estómago e intestinos del lenguado se distribuye ampliamente en peces marinos, ya que parasita a los lenguados Paralichthys dentatus en Woods Hole, Massachusetts (Linton, 1905) y en $P$. albiguttatus en Beaufort, Florida (Manter, 1947). Se ha registrado en los intestinos de $P$. californicus en La Jolla, California (Manter y Van Cleave, 1951), de Dassycottus setiger en Colombia Británica (Arai, 1969), de Embiotoca jacksoni en Baja California (Arai, 1962), y de Sebastes aleutianus, S. babcocki y S. borealis del Pacífico Norte (Sekerak y Arai, 1977). Aunque no se conoce el ciclo de vida de $S$. dentatum, se sabe que utilizan a gasterópodos como primer hospedante intermediario y a una gran variedad de peces, tanto marinos como dulceacuícolas, como segundo hospedante intermediario y definitivo, respectivamente (Martin, 1939). babcocki and $S$. borealis of the North Pacific (Sekerak and Arai, 1977). Although the life cycle of $S$. dentatum is not known, they do use gastropods as their first intermediate host, and a wide variety of both marine and fresh-water fish as their second intermediate and definitive host, respectively (Martin, 1939).

The digenean $T$. lindbergi has the greatest number of synonymies and, because of its high intraspecific morphological variability, many species have erroneously been reported as new. It parasitizes Sparus macrocephalus of Japan (Yamaguti, 1934), eight species of fish from Oregon (McCauley, 1960) and Leptocottus armatus, $P$. californicus and Hypsopsetta guttulata of San Quintin Bay (King, 1962).

The high values of prevalence and abundance of infection in $P$. californicus at the three sites studied corresponded to larvae of Anisakis sp. and plerocercoids of the order Tetraphyllidea. This concurs with studies that report many species of teleosts as intermediate hosts (Thoney, 1993; Castillo-Sánchez et al., 1997), ending the biological cycle in marine mammals in the first case and in elasmobranchs (rays or sharks) in the second (Anderson, 1992; Euzet, 1994). This confirms the role of $P$. californicus in the transmission dynamics of helminths.

The high values of infection of Anisakis sp. larvae indicate the potential risk for zoonosis, since this nematode has been reported on a number of occasions in other parts of the world as the causal agent of anisakiasis in humans (Sakanari, 1990; Williams and Jones, 1994). These nematodes (Anisakinae) parasitize many marine fish frequently consumed by humans, in places such as Poland, Norway, Germany, France, Hawaii, Indonesia, Japan, Korea, Chile, Brazil and USA (Williams and Jones, 1994). The California halibut is economically important for Baja California and California (Hammann and Ramírez-González, 1990), but it is important to note the risk it presents if consumed raw or insufficiently cooked. The Tetraphyllidae have a cosmopolitan distribution and the adults parasitize the spiral valve of elasmobranchs and holocephali 
El digénido 7 . lindbergi presenta el mayor número de sinonimias y. por su alta variabilidad morfológica intraespecifica, varias especies se han descrito como nuevas por error. Parasita' a Sparus macrocephalus de Japón (Yamaguti, 1934). a ocho especies de peces de Oregon (McCauley, 1960), y a Leptocottus armatus. P. californicus e Hypsopsetta guttulata de la Bahía de San Quintín (King, 1962).

Los valores altos de prevalencia y abundancia de infección en $P$. californicus en los tres sitios estudiados correspondieron a las larvas de Anisakis sp. y a plerocercos del orden Tetraphyllidea. Esto concuerda con reportes de que muchas expecies de teleósteos han sido registradas como hospedantes intermediarios (Thoney, 1993; Castillo-Sánchez et al., 1997), cerrando el ciclo biológico en mamíferos marinos en el primer caso y en elasmobranquios (rayas o tiburones) en el segundo (Anderson, 1992: Euzet, 1994). Esto ratifica el papel de P. californicus en la dinámica de transmisión de helmintos.

Los valores altos de infección de las larvas de Anisakis sp. determina un riesgo polencial a una zoonosis parasitaria, pues este nematodo ha sido registrado en numerosas ocasiones en otras partes del mundo como el agente causal de la anisakiasis en los humanos (Sakanari, 1990; Williams y Jones, 1994). Estos nematodos (Anisakinae) parasitan un número elevado de peces marinos de frecuente consumo humano, en lugares como Polonia, Noruega, Alemania, Francia, Hawaii, Indonesia, Japón, Corea, Chile, Brasil y EUA (Williams y Jones, 1994). El lenguado de California es un recurso de importancia econónica en la zona de Baja California y California (Hammann y Ramírez-Gonzalez, 1990), pero es necesario señalar el riesgo que representa su consumo en forma cruda o insuficientemente cocida. Los Tetraphyllidea tienen distribución cosmopolita y los adultos parasitan la válvula espiral de elasmohranquios y holocéfalos (Euzet, 1994). Sus larvas se registran en muchos teleósteos que actían como hospedantes paraténicos (Kennedy, 1983). En México se han registrado en Euthynnus
(Euzet, 1994). Their larvae are found in many teleosts that act as paratenic hosts (Kennedy, 1983). In Mexico, they have been reported for Euthunnus lineatus at Chamela Bay, Jalisco (Castillo-Sánchez et al., 1997).

Corynosoma strumosum is considered of circumboreal distribution and forms part of the 11 reported for the North Pacific that parasitize birds and marine mammals (Van Cleave, 1953). It has been found in the juvenile stage as a parasite of Onchorhynchus nerka and $O$. gorbuscha of the North Pacific (Margolis, 1985), and as an adult in Zalophus californianus in California, USA (Lincicome, 1943). Many species designated to the genus Philometra are not completely described, because it is not common for males to occur, since when the female is fertilized, they die and are reabsorbed (Anderson. 1992).

This study contributes to the knowledge of the biology of the California halibut ( $P$. californicus) by establishing the record of helminths that it hosts. This information is of great importance, both for evaluating the potential impact the parasites could have on this fish, and for implementing sanitation controls to avoid the development of helminths in $P$. californicus mariculture.

English translation by Jennifer Davis.

lineatus de la Bahía de Chamela, Jalisco (CastilloSánchez et al., 1997).

Corynosoma strumosum se considera de distribución circumborcal y forma parte de las 11 registradas para el Pacífico Norte que parasitan aves y mamíferos marinos (Van Cleave, 1953). Se le ha registrado en estadio juvenil como parásito de Onchorhynchus nerka y $O$. gorbuscha del Pacifico Norte (Margolis, 1985), y como adulto en Zalophus californianus en California, EUA (Lincicome, 1943). Muchas especies designadas al género Philometra se describen de forma incompleta porque no es común que los machos aparezcan, pues cuando la hembra es fertilizada 
éstos mueren y son reabsorbidos (Anderson, 1992).

Finalmente, en el presente estudio se contribuye al conocimiento de la biología del lenguado de California ( $P$. californicus) al establecer el registro de los helmintos que lo parasitan. Esta información puede ser de gran importancia, tanto para la evaluación del impacto potencial que los parásitos podrían tener sobre este pez, como para implementar medidas de control sanitario que eviten el desarrollo de la helmintiasis en caso de intentar establecer maricultivo de $P$. californicus.

\section{REFERENCIAS}

Acosta-Ruiz, M. y Álvarez-Borrego, S. (1974) Distribución superficial de algunos parámetros hidrológicos. físicos y químicos en el Estero de Punta Banda, BC, en otoño e invierno. Ciencias Marinas. I(1): 10-45

Anderson, (.B. (1992). Nematode Parasites of Vertebrates: Their Development and Transmission. CAB International. $578 \mathrm{pp}$.

Andrade-Salas, O., Pineda-López, R.F. and GarciaMagaña, L. (1994). Spirocamallanus rebecae sp. $n$. (Nematoda: Camallanidae) from freshwater tishes in south-eastern Mexico. Folia Parasitologica, 41: 259-270.

Arai, P.H. (1962). Trematodos digéneos de peces marinos de Baja California, México. An. Inst. Biol. Univ. Nac. Autón. Méx., 33: 113-130.

Arai, P.1H. (1969). Preliminary report on the parasites of certain marine fishes of British Columbia. J. Fish. Res. Board Canada. 26(9): 1337-2319.

Bane, G.W. and Bane, A.W. (1971). Bay Fishes of Nothern California. Mariscos Publ,, Hampton Bays, New York, 143 pp.

Bray, A.R. (1990). A review of the genus Parahemiurus Vaz and Pereira, 1930 (Digenea: Hemiuridae). Syst. Parasitol., 15: 1-21.

Castillo-Sánchez, E., García-Prieto, L. y Pérez-Ponce de León, G. (1997). Helmintofauna del barrilete Euthynnus lineatus de la Bahia de Chamela, Jalisco, México. Rev. Biol. Trop., 45(3): 125l1253 .

Contreras, F. (1985). Las Lagunas Costeras Mexicanas. 2da ed. Centro de Ecodesarrollo, Secretaría de Pésca, México, 263 pp.
Deardoff, L.T. and Overstreet, R.M. (1981). Review of Hysterothylacium and Iheringascaris (both previously = Thynnascaris) (Nematoda: Anisakidae) from the northern Gulf of Mexico. Proc. Biol. Soc. Wash., 93(4): 1035-1079

Dogiel, V.A. (1964). General Parasitology. Oliver and Boyd, London, $516 \mathrm{pp}$.

Euzet, L. (1994). Order letraphyllidea Carus, 1863. In: L.F. Khalil, A. Jones and R.A. Bray (eds.), Keys to the Cestode Parasites of Vertebrates. CAB International. Cambridge, pp. 149-194.

Haaker, P.L. (1975). The biology of the California halibut Paralichthys californicus (Ayres) in Anaheim Bay, California. In: L.D. Lane and C.W. Hill (eds.), The Marine Resources of Anaheim Bay. Calif. Dept. Fish and Game, Fish. Bull., pp. 137-151

Hammann, G.M. y Rosales-Casián. J.A. (1990). Taxonomía y estructura de la comunidad de peces del Estero de Punta Banda y Bahia de Todos Santos, BC, México. Cap. 6. En: J. Rosa-Vélez y F. González-Farías (eds.), Temas de Oceanografía Biológica en México. Universidad Autónoma de Baja California, Ensenada, $337 \mathrm{pp}$.

Hammann, G.M. and Ramírez-González, A.A. (1990). California halibut, Paralichthys californicus, in Todos Santos Bay, Baja California, México. Fish Bull., 174: 127-144.

Ibarra-Obando, S.L. (1990). Lagunas costeras de Baja California. Ciencia y Desarrollo, XVI (92): 39-49.

Kennedy, C.R. (1983). General ecology. In: C. Arme y P.W. Pappas (eds.), Biology of the Eucestoda. Vol. I. Academic Press, New York, pp. 27-80.

King, E.R. (1962). A new species of Parahemiurus and notes on Tubulovesicula lindbergi (I rematoda: Hemiuridae) from fishes of Bahia de San Quintín, Baja California. Pac. Naturalist. 3(10): 331-336.

Kramer, S.H. (1991). Mortality and movements of juvenile California halibut Paralichthys californicus in shallow coastal and bay habitats of San Diego County, Calitornia. Fish. Bull. US, 89: 195-207.

Lamothe-Argumedo, R., Garcia-Prieto, L., OsorioSarabia, D. y Pérez-Ponce de León, G. (1997). Catálogo de la Colección Nacional de Helmintos. Publ. Esp. Inst. Biol. Univ. Nal. Autón. Méx., CONABIO, $211 \mathrm{pp}$.

León-Regagnon, V., Pérez-Ponce de Leén, G. and Garcia-Prieto, L. (1997a). Description of a new species, Heteroplectanum olivierl $\mathrm{sp}$. $\mathbf{n}$. 
(Monogenea: Monopisthocolylea: Diplectanidae). and comments on the helminth fauna of Kyphosus elegans Peters, 1869 (Perciformes: Kyphosidae) from (hamela Bay, Mexico. J. Itelmintol. Soc. Wash., 64(1): (). 17.

l.cón-Regagnon. V., Pérez-Ponce de León, G. y I amothe-Argumedo, R. (1997b). Hemiuriformes de poess marinos de la Bahia de Chamela. Méxieo, con la descripción de una nueva especie del género Ihsterolecitha Linton 1910 (Digenea: I lemiuridae: Lecithasterinac). An. Ins. Biol. Univ. Nal. Autón. Méx. 68(1): 1-34.

1.incicome. R.D. (1943). Acanthocephala of the genus (orynosoma from the California sea-lion. I. Parasitol, 29: 102-106.

1.inton. E. (1905). Parasites of fishes of Beaufort. North Carolina. Bul1. US Bur. Fish. (1904) 24: 321-428.

Love. S.M. and Moser, M. (1983). A checklist of parasites of California. Oregon and Washington marine and estuarine lishes. Tech. Rep. Dept. Commerce. Natl. Oceanic \& Atmos. Admin. NMFS California. $576 \mathrm{pp}$.

Mantcr. II.W. (1940). Digenetic trematodes of (ialapagos Islands and the neighbouring Pacific. Allan Hancock Pac. Exped.. 2: 329-496.

Manter. II.W. (1947). The digenetic trematodes of marine fishes of Tortugas, Florida. Am. Midl. Nat.. 38: $257-416$.

Mantcr. H.W and Van (leave, H.J. (1951). Some digenetic trematodes including eight new species from marine tishes of La Jolla, California. Proc. IS Nat. Mus. 101: 315-339.

Marcogliese. 1.D. (1996). Larval parasitic nematodes infecting marine crustaceans in eastern Canada. 3. IS sterothylacium aduncum. I. Helminthol. Soc. Wash.. 63: 12-18.

Margolis. I. (i. (1985). The occurrence of juvenile Corynosoma (Acanthocephala) in Pacific salmon (Onchorhynchus spp.). J. Fish. Res. Board Canada, 15(5): 983-990.

Margolis. L.C... Esch. W.. Ilolmes. J.C.. Kurris, M.A. and shad. A.G. (1982). The use of ecological terms in parasitology. J.Parasitol., 68(12): 131-133.

Martin. W.I. (1939). Studies on the trematodes of Woods Ilole. II. The life cycle of Stephanostomum teme (Linton). Biol, Bull.. 77: 65-73.

McCaulcy. I.J. (1960). Some hemiurid trematodes of Oregon marine fishes. J. Parasitol. 46: 84-89.

Myers, J.B. (1975). The nematodes that cause Anisakiasis. I. Milk rood Technol., 39(1/2): 3246.
Norris, E.D. and Overstreet. R.M. (1975). The public health implications of larval Thymnascaris nematodes from shellish. J. Milk. Food Technol.. $39(1): 47-54$

Olsen, S.L. (1952). Some nematodes parasitic in marine fishes. Publ. Inst. Mar. Sci. Univ. Texas, 2: $173-215$

Olson, C.A.. Lewis, M.D. and Ilauser. M.L. (1983) Proper identification ol Anisakinae worms. Am. J. Medical Technol., 49(2): 111-114.

Overstrect. R.M (1969). Digenetic trematodes of marine teleost lishes from Biscayne Bay, Florida. Tulane Studies in /oology and Botany, 15: 119-176.

Roberts, D., de Martini, I:, Engel. C. and Plummer, K. (1981). A preliminary evaluation of prey selection by juvenile-small adult California halibut (Paralichthys californicus) in nearshore coastal waters off southern Californial In: G.M. Cailliet and C.A. Simenstad (cds.), Gut Shop' 81. Fish Food Habits Studies. Wash. Sea Grant Publ., Univ. Wash., Seattle. pp. 214-233

Rosales-Casián, J.A. (1996). Retiofauna de Bahía de San Quintin. Baja (alifornia. México. y su costa adyacente. Ciencias Marinas, 22(4) 443-458.

Rosales-Casián, J.A. (1997). Inshore soft-bottom fishes of two coastal lagoons on the northern Pacitic coast of Baja California. CalCOFl Rep.. 38: 180-192.

Sakanari, J.A. (1990). Anisakis from the platter to the microfuge. Parasitol. Foday, $6(10): 323-327$.

Secretaría de Marina (1974). Estudio (iengrático de la Región de Ensenada. BC. México. Seceretaria de Marina. México, DF, $465 \mathrm{pp}$.

Sekerak, A.P. and Arai, H.P. (1977). Some metazoan parasites of rockfishes of the gacnus Sehastes from the northeastern Pacific Ocean. Syesis, 10: $139-144$.

Sogandares-13ernal, F. (1959). Digenctic trematodes of marine fishes from the (iulf of Panama and Bimini, British West Indies. Tulane Stud Zool., 7: 69-117.

Thoncy, A.D. (1993). Commenity conlogy of the parasites of adult spot, Leistomes xanthurus, and Atantic croaker. Micropogonias undulatus (Scianidac), in the (ape llatteras region. I. Fish Biol. 43: 781-804.

Van Cleave, J.H. (1953). A preliminary analysis of the acanthocephalan genus (orynosoma in mammals of North America. J. Parasitol. 39(1): 1-13

Williams. II. and Jones, A. (1994). Parasitic Worms of Fishes. Taylor and Francis, London. $593 \mathrm{pp}$ 
Ciencias Marinas, Vol. 24, No. 4, 1998

Yamaguti, S. (1934). Studies on the helminth fauna of Japan. Part 2. Trematodes of fishes I. Japan. J. Zool., 5: 249-541.

Yamaguti, S. (1971). Synopsis of Digenetic Trematodes of Vertebrates. Vol. I. Keigaku Publ, Tokyo, $1074 \mathrm{pp}$.
Yamaguti, S. (1975). A Synoptical Review of Life Histories of Digenetic Trematodes of Vertebrates. Keigaku Publ., Tokyo, 590 pp. 